Article

\title{
Large Introns of 5 to 10 Kilo Base Pairs Can Be Spliced out in Arabidopsis
}

\author{
Ning Chang, Qingqing Sun, Jinglei Hu, Chuanjing An (1) and Hongbo Gao * \\ College of Biological Sciences and Technology, Beijing Forestry University, Beijing 100083, China; \\ ningjing890115@126.com (N.C.); sunqq@bjfu.edu.cn (Q.S.); hjlei@bjfu.edu.cn (J.H.); anchuanjing@163.com (C.A.) \\ * Correspondence: gaohongbo@bjfu.edu.cn; Tel.: +86-010-6233-6496
}

Received: 7 July 2017; Accepted: 7 August 2017; Published: 11 August 2017

\begin{abstract}
Most of the eukaryotic genes contain introns, which are removed from the pre-RNA during RNA processing. In contrast to the introns in animals, which are usually several kilo base pairs $(\mathrm{kb})$, those in plants generally are very small, which are mostly from dozens of base pairs (bp) to a few hundred bp. According to annotation version 10.0 of the genome of Arabidopsis thaliana, there are 127,854 introns in the nuclear genes; $99.23 \%$ of them are less than $1 \mathrm{~kb}$, and only 16 introns are annotated to be larger than $5 \mathrm{~kb}$, which are extremely large introns (ELI) in Arabidopsis. To learn whether these introns are true introns or not and how large introns could be in Arabidopsis, RT-PCR analysis of genes containing these ELIs were carried out. The results indicated that some of these putative introns are indeed ELIs. These ELIs are mainly composed of transposons or transposable elements (TE), excepting one, whose counterparts are also very long in diverse plant species. Thus, this study confirms the existence of introns larger than $5 \mathrm{~kb}$ or even $10 \mathrm{~kb}$ in Arabidopsis.
\end{abstract}

Keywords: Arabidopsis; large intron; transposon; reverse transcription PCR

\section{Introduction}

Introns are a common and important feature of eukaryotic genes. It is the nucleotide sequence within a gene that is spliced out during the maturation of RNA. The splicing of RNA is a part of RNA processing pathway after the transcription and before the translation. Through RNA splicing, introns are removed and the exons are ligated to form the mature RNA product. Introns are found in the genes of most organisms and many viruses and exist in a wide range of genes, including protein coding messenger RNA (mRNA), ribosomal RNA (rRNA), and transfer RNA (tRNA) [1]. Introns in multicellular eukaryotes are evenly distributed throughout genes, including protein coding region and $5^{\prime}$ and $3^{\prime}$ untranslated region (UTR) [2].

The lengths of introns vary widely among different organisms and different genes. Generally, the sizes of introns in animal genes are larger than those in plant genes. For example, human genes tend to have small exons separated by long introns with the mean and median size of 3356 and 1023 $\mathrm{bp}$, respectively [3]. In contrast, analyses of genes in Arabidopsis thaliana and maize indicated that their introns are substantially shorter than those in humans. The mean and median lengths of introns are 168 and $100 \mathrm{bp}$ in Arabidopsis [4]. In maize, the mean and median lengths of introns are 516 and $146 \mathrm{bp}$ [5]. The average intron size in Physcomitrella patens is $311 \mathrm{bp}$ [6]. Similar to plant introns, introns in Schizosaccharomyces pombe (93 bp on average), Drosophila melanogaster (564 bp on average), and Caenorhabditis elegans (467 bp on average) are also substantially shorter [7]. Variations of the lengths and structures of introns among different genomes suggest that extensive gain and loss of intron sequences is common during evolution.

In our studies, we found that some of the introns in Arabidopsis have a length of several $\mathrm{kb}$, which are very large and rare for Arabidopsis. Therefore, we wanted to know how large the introns 
in Arabidopsis can be. In this study, we systematically analyzed the sizes of introns in the genome of $A$. thaliana. We found that although $99.23 \%$ of the introns are shorter than $1 \mathrm{~kb}$, a very small part of the introns are annotated or predicted to be larger than $5 \mathrm{~kb}$, and in very rare case, introns are annotated to be larger than $10 \mathrm{~kb}$. Because these introns are extremely large in Arabidopsis, we wanted to investigate whether they are true introns or not. The existence of some of them was validated by reverse transcription PCR (RT-PCR) analysis and DNA sequencing in this study, and sequences of these introns were also analyzed to reveal their origin and evolution. The implications of the results are also discussed.

\section{Materials and Methods}

\subsection{Bioinformatics Analysis}

Sequences of introns in A. thaliana and the related information were retrieved from the BLAST data sets at TAIR website (http:/ / www.arabidopsis.org, version database 10). Statistical analysis of the length of the introns was carried out via Microsoft Excel. Gene structure analysis of Arabidopsis genes was done manually and assisted with the information from TAIR and SALK T-DNA express (http://signal.salk.edu/cgi-bin/tdnaexpress/). Primers from the exons before and after the annotated large intron were designed for RT-PCR analysis. Multiple protein sequence alignments were done with CLUSTAL W. To investigate the intron information in other species, BLAST against the genome sequences with Arabidopsis protein sequences was carried out with NCBI tBLASTN (http:/ /blast.ncbi. nlm.nih.gov/Blast.cgi). The lengths of the introns were calculated manually based on the boundary of intron/exon defined by the RT-PCR product and compared with the genomic sequence.

\subsection{Plant Materials and Growth Conditions}

A. thaliana plants used in this study were Columbia-0 (Col-0) and Landsberg (Ler) ecotypes. Seeds were sowed in soil or on Murashige and Skoog (MS) plates and then placed in the growth chamber under long-day conditions ( $16 \mathrm{~h} \mathrm{light} / 8 \mathrm{~h}$ of darkness) at $22^{\circ} \mathrm{C}$. Leaves of four-week-old plants grown in soil, floral tissues, and one-week-old seedlings grown on MS plates were used for RNA isolation.

\subsection{Total RNA Isolation and RT-PCR Analysis}

Total RNA was extracted by the RNeasy Plant Kit (Aidlab, Beijing, China). For RT-PCR analysis, total RNA was reverse-transcribed with RevertAid First Strand cDNA Synthesis Kit (Fermentas, Waltham, MA, USA). Complementary DNA (cDNA) of AT3G60961, AT1G58602, AT3G05410, and AT5G13250 were amplified with primers indicated in Figure 2 and listed in the Table S1. PCR products were sequenced, and the sequences were aligned with the genome sequence and compared with the annotated sequence.

\section{Results}

\subsection{Analysis of the Distribution of Intron Sizes in the Genome of Arabidopsis thaliana}

According the annotation version TAIR 10 of the Arabidopsis genome, there are 127,854 introns in the nuclear genome. After analyzing the lengths of all the introns, we found that a large part $(48.93 \%)$ of the introns is below $100 \mathrm{bp}$, and $50.30 \%$ of the introns are between 100 and $999 \mathrm{bp}$ (Figure 1A). These introns constitute $99.23 \%$ of the introns in the genome of Arabidopsis. There are 979 introns larger than $1 \mathrm{~kb}$, which is only $0.77 \%$ (a very small part) of the total introns. Introns larger than $3 \mathrm{~kb}$ are very rare, with only 58 in the nuclear genome. There are 16 introns annotated to be larger than $5 \mathrm{~kb}$, which we labeled as extremely large introns (ELI) in Arabidopsis in this study (Figure 1B). Among those 16 ELIs, eight are located in protein-coding genes, four are in pseudogenes, two are in potential natural antisense genes, and two are obsolete or no longer exist (Table 1 and Table S2). AT1G24880.1-3 and AT1G25054.1-3 are obsolete and not investigated in this study. These annotated ELIs often contain 
transposons or transposable elements (TEs). Some of them also contain one or more genes. Rarely, some of the intron sequences are just non-repetitive sequences.

A

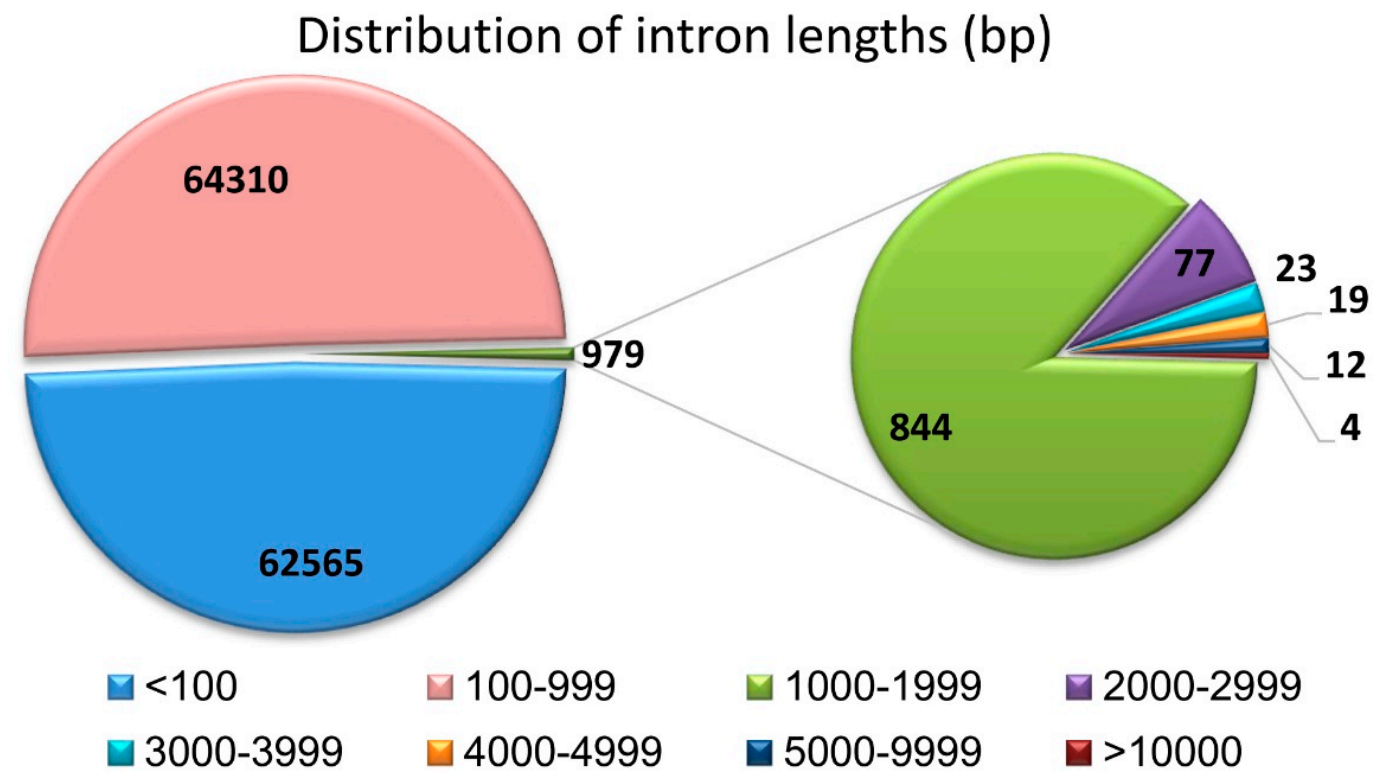

B

\section{1}

Intron length (bp)

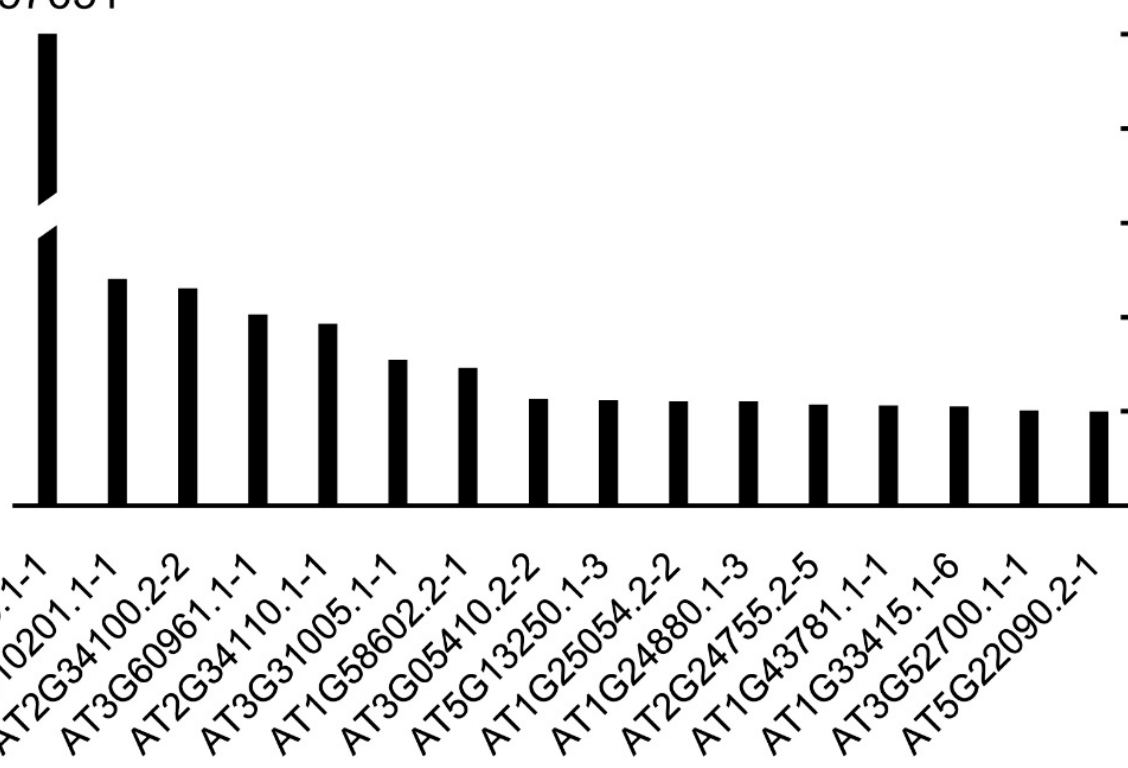

Figure 1. The distribution of intron lengths in Arabidopsis thaliana according to the annotation of TAIR10. (A) In the genome of $A$. thaliana, there are 127,854 introns of nuclear genes ranging from $8 \mathrm{bp}$ to 57,631 bp. Among those, 62,565 introns are shorter than $100 \mathrm{bp}$, while 64,310 introns are from 100 to $999 \mathrm{bp}$. There are $844,77,23,19,12$, and 4 introns in the range of 1000-1999 bp, 2000-2999 bp, 3000-3999 bp, 4000-4999 bp, 5000-9999 bp, and >10,000 bp, respectively. (B) A list of introns larger than $5000 \mathrm{bp}$. 
Table 1. An analysis of the introns larger than $5 \mathrm{~kb}$ in protein coding genes in A. thaliana.

\begin{tabular}{|c|c|c|c|c|c|c|}
\hline Gene & $\begin{array}{c}\text { Annotated } \\
\text { Intron }\end{array}$ & $\begin{array}{c}\text { Length } \\
\text { (bp) }\end{array}$ & $\begin{array}{l}\text { Validation } \\
\text { Results }\end{array}$ & Description of Gene & $\begin{array}{l}\text { Description of } \\
\text { Intron }\end{array}$ & $\begin{array}{l}\text { Total Size of } \\
\text { TEs in } \\
\text { the Intron }\end{array}$ \\
\hline AT2G34100.2 & AT2G34100.2-2 & 11,602 & $\begin{array}{l}\text { Validated; } \\
11,602 \text { bp }\end{array}$ & $\begin{array}{l}\text { Nonsense-mediated } \\
\text { mRNA decay-like } \\
\text { protein }\end{array}$ & $\begin{array}{c}\text { This intron contains } \\
\text { 13 genes or TEs: } \\
\text { AT2TE63770, } \\
\text { AT2G34110, } \\
\text { AT2TE63775, } \\
\text { AT2TE63780, } \\
\text { AT2G34120, } \\
\text { AT2TE63785, } \\
\text { AT2G34123, } \\
\text { AT2TE63790, } \\
\text { AT2TE63795, } \\
\text { AT2TE63800, } \\
\text { AT2G34130, } \\
\text { AT2TE63805, } \\
\text { AT2G34135, with } \\
\text { different sizes. }\end{array}$ & $\begin{array}{l}6325 \mathrm{bp} \\
(54.52 \%)\end{array}$ \\
\hline AT3G60961.1 & AT3G60961.1-1 & 10,234 & $\begin{array}{l}\text { Validated; } \\
10,247 \text { bp }\end{array}$ & $\begin{array}{l}\text { P-loop containing } \\
\text { nucleoside } \\
\text { triphosphate } \\
\text { hydrolases } \\
\text { superfamily protein }\end{array}$ & $\begin{array}{c}\text { This intron was also } \\
\text { annotated as } \\
\text { AT3G60965, a } \\
\text { copia-like } \\
\text { retrotransposon. }\end{array}$ & $\begin{array}{c}9903 \mathrm{bp} \\
(96.64 \%)\end{array}$ \\
\hline AT2G34110.1 & AT2G34110.1-1 & 9724 & $\begin{array}{c}\text { Not } \\
\text { validated }\end{array}$ & hypothetical protein & NA & \\
\hline AT1G58602.1 & AT1G58602.1-1 & 7384 & $\begin{array}{l}\text { Validated; } \\
7385 \text { bp }\end{array}$ & $\begin{array}{l}\text { LRR and NB-ARC } \\
\text { domains-containing } \\
\text { disease resistance } \\
\text { protein }\end{array}$ & $\begin{array}{l}\text { This intron contains } \\
4 \text { TEs: AT1TE71765, } \\
\text { AT1TE71770, } \\
\text { AT1TE71775 and } \\
\text { AT1TE71780. }\end{array}$ & $\begin{array}{l}6164 \mathrm{bp} \\
(83.47 \%)\end{array}$ \\
\hline AT1G58602.1 & $\begin{array}{l}\text { AT1G58602.1-2 } \\
\text { and } \\
\text { AT1G58602.1-3 }\end{array}$ & 6070 & $\begin{array}{l}\text { Validated; } \\
6070 \text { bp }\end{array}$ & $\begin{array}{l}\text { LRR and NB-ARC } \\
\text { domains-containing } \\
\text { disease resistance } \\
\text { protein }\end{array}$ & $\begin{array}{c}\text { These two annotated } \\
\text { introns and the exon } \\
\text { between them were } \\
\text { found to be an intron } \\
\text { of } 6070 \text { bp. It } \\
\text { contains } 10 \text { TEs: } \\
\text { AT1TE71785, } \\
\text { AT1TE71790, } \\
\text { AT1TE71795, } \\
\text { AT1TE71800, } \\
\text { AT1TE71805, } \\
\text { AT1TE71810, } \\
\text { AT1TE71815, } \\
\text { AT1TE71820, } \\
\text { AT1TE71825 and } \\
\text { AT1TE71830. }\end{array}$ & $\begin{array}{l}5192 \mathrm{bp} \\
(85.54 \%)\end{array}$ \\
\hline AT3G05410.2 & AT3G05410.2-2 & 5748 & $\begin{array}{l}\text { Validated; } \\
5748 \text { bp }\end{array}$ & $\begin{array}{l}\text { Photosystem II } \\
\text { reaction center } \\
\text { OEC23 protein }\end{array}$ & $\begin{array}{c}\text { A major part of the } \\
\text { intron is a } \\
\text { transposon, } \\
\text { AT3TE06550. }\end{array}$ & $\begin{array}{l}5261 \mathrm{bp} \\
(91.53 \%)\end{array}$ \\
\hline AT5G13250.1 & AT5G13250.1-3 & 5670 & $\begin{array}{l}\text { Validated; } \\
5673 \text { bp }\end{array}$ & RING finger protein & $\begin{array}{l}\text { This intron contains } \\
\text { AT5TE15340, } \\
\text { AT5TE15345, } \\
\text { AT5TE15350 and } \\
\text { AT5G02075, which } \\
\text { constitute only a } \\
\text { small part of the } \\
\text { intron. }\end{array}$ & $530 \mathrm{bp}(9.34 \%)$ \\
\hline AT3G52700.1 & AT3G52700.1-1 & 5134 & $\begin{array}{c}\text { Not } \\
\text { validated }\end{array}$ & Hypothetical protein & NA & \\
\hline AT5G22090.2 & AT5G22090.2-1 & 5082 & $\begin{array}{l}\text { Validated; } \\
5082 \text { bp }\end{array}$ & FAF-like protein & $\begin{array}{c}\text { This intron contains } \\
3 \text { TEs: AT5TE26450, } \\
\text { AT5TE26455, } \\
\text { AT5TE26460 }\end{array}$ & $\begin{array}{c}1985 \mathrm{bp} \\
(39.06 \%)\end{array}$ \\
\hline
\end{tabular}

TE: transposable element; mRNA: messenger RNA; LRR: leucine-rich repeat; NB: Nucleotide Binding; ARC: Apaf-1, certain R gene products, and CED-4; OEC: Oxygen-Evolving Complex; RING: Really Interesting New Gene; FAF: Fantastic Four; NA: not applicable.

\subsection{Validation and Sequence Analysis of Extremely Large Introns in Arabidopsis}

To learn whether these ELIs are true introns or not, eight ELIs, the ones located in the protein-coding genes, were chosen for validation by RT-PCR and sequencing analysis (Table 1, Figures 2 
and 3). RT-PCR analysis of the RNA extracted from four-week old leaves (Figure 2A) validated the ELIs in AT3G60961.1 AT1G58602.1 AT3G05410.2 AT5G13250.1. A further RT-PCR analysis of the RNA extracted from floral tissues (Figure 2B) validated the ELIs in AT2G34100.2 and AT5G22090.2. The annotated ELI in AT3G52700.1 could not be validated (Figure S1). The RT-PCR products of AT2G34110.1 were sequenced and found to be an unrelated sequence. Overall, six of them were validated, two of them were not, and a new ELI was discovered (Figure 2).

AT3G60961.1 encodes a protein of the P-loop containing nucleoside triphosphate hydrolases superfamily. The first intron of this gene, AT3G60961.1-1, was annotated to be 10,233 bp. A pair of primers (Figure 2A) located at the two exons before and after this intron was designed to validate the existence of this intron by RT-PCR analysis. As shown in Figure 3A, PCR products with an expected size were amplified. Further sequencing analysis indicated that the transcript is almost the same as the one annotated, except the $5^{\prime}$ splicing site of the intron is $13 \mathrm{bp}$ upstream. This intron was also annotated as AT3G60965, which is a copia-like retrotransposon and constitutes $96.6 \%$ of the intron. There are also transposable elements before and after this gene.

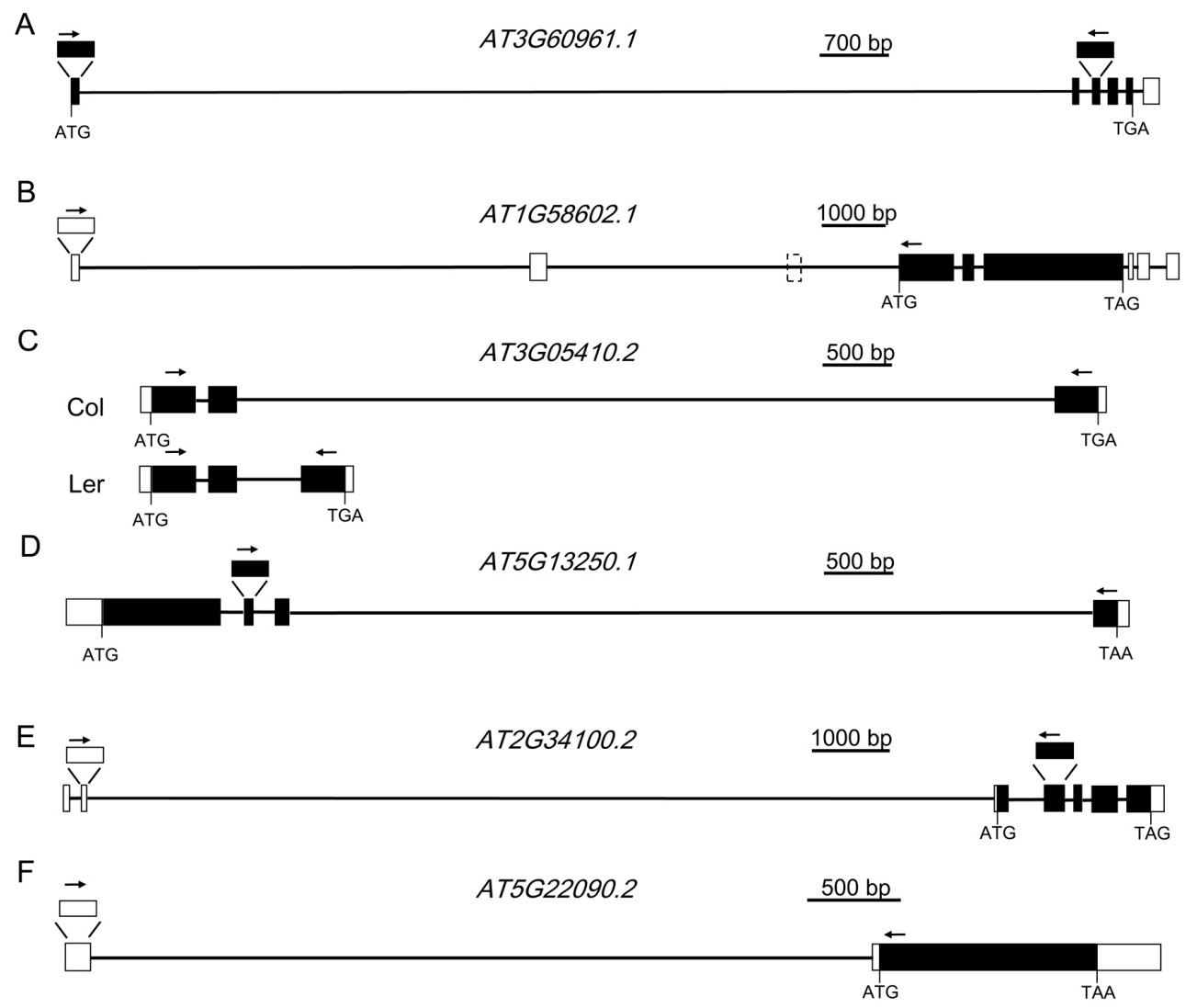

Figure 2. Gene structures of AT3G60961.1, AT1G58602.1, AT3G05410.2, AT5G13250.1, AT2G34100.2, and AT5G22090.2. (A) The structure of AT3G60961.1. (B) The structure of AT1G58602.1. (C) The structure of AT3G05410.2 in Col and Ler ecotype. (D) The structure of AT5G13250.1. (E) The structure of AT2G34100.2. (F) The structure of AT5G22090.2. White boxes represent the 5' and 3' untranslated region (UTR), black boxes represent the coding sequence, and black lines represent the intron. Arrows indicate the positions of forward and reverse primers for RT-PCR analysis. 
A

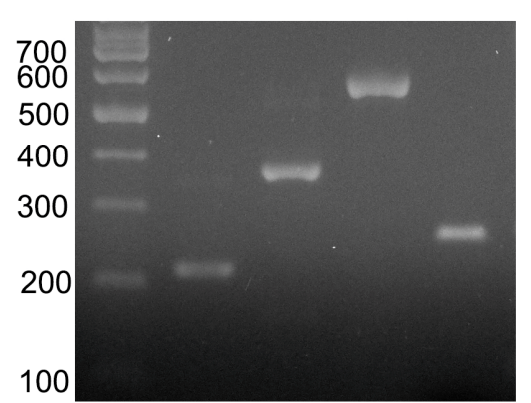

(bp)
B

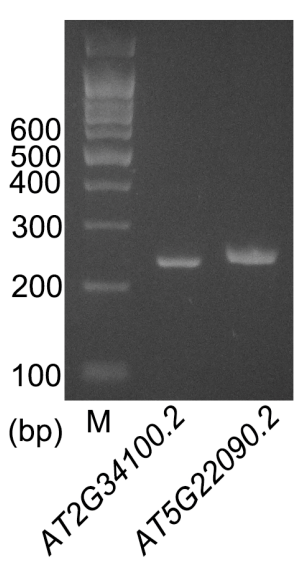

C

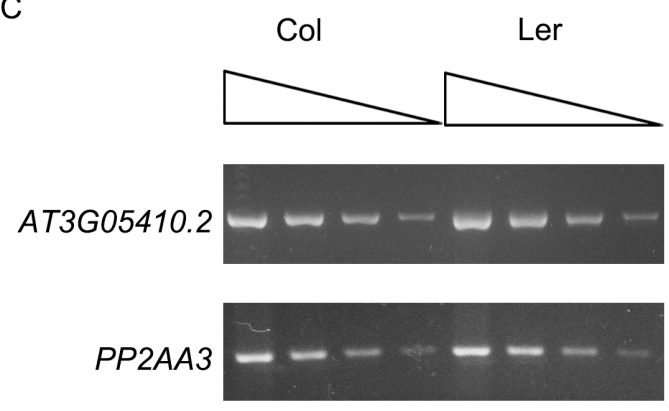

Figure 3. RT-PCR analysis of the genes shown in Figure 2. (A) RT-PCR analysis of AT3G60961.1, AT1G58602.1, AT3G05410.2, and AT5G13250.1 with RNA extracted from leaves. Positions of primers are shown in Figure 2. (B) RT-PCR analysis of AT2G34100.2 and AT5G22090.2 with RNA extracted from floral tissues. Positions of primers are shown in Figure 2. (C) Semi-quantitative RT-PCR analysis of AT3G05410.2 in Col and Ler ecotype. Black triangles above indicate that the quantity of cDNA was serially diluted three times with a dilution factor of four (from left to right). PP2AA3 gene (AT1G13320) was used as a control.

AT1G58602.1 encodes a disease resistance protein with LRR and NB-ARC domains. The 5'-UTR of this gene was annotated to have three introns, with the first intron found to be $7384 \mathrm{bp}$. A pair of primers located at the first and the fourth annotated exon (Figure 2B) was designed to validate the existence of this intron by RT-PCR analysis. DNA sequencing results validated the first intron. Surprisingly, the third exon was missing in the transcript, suggesting that the second intron, the second exon, and the third intron are all spliced out. Therefore, this intron, $6070 \mathrm{bp}$ in size, is a newly discovered extremely large intron in Arabidopsis. The first intron contains AT1G58561, a copia-like retrotransposon, and several other TEs. The second intron reported here also contains several TEs. The genomic regions before or after this gene also contain multiple TEs.

AT3G05410 encodes a Photosystem II reaction center protein, OEC23 (or PsbP). It has multiple alternative splice variants. The second intron of AT3G05410.2 is $5748 \mathrm{bp}$ long, and was validated by our RT-PCR analysis. This intron is mainly composed of AT3TE06550, which belongs to non-LTR retrotransposon family (LINE). The protein AT3G05410 and its closest homolog in Arabidopsis, AT3G55330, have an identity of $25 \%$ and an $E$ value of $5 \times 10^{-10}$ when a BLAST search was done at TAIR. However, it was shown to have an identity of $86 \%$ and an $E$ value of $2 \times 10^{-172}$ with its homolog in Raphanus sativus in a BLAST search at the National Center for Biotechnology Information (NCBI). This suggests AT3G05410 is a single copy gene in the genome of Arabidopsis and it is an essential gene for photosynthesis. The exon after this intron is not included in AT3G05410.1. However, the coding sequence of this exon is well conserved in different plant species (Figure S2), suggesting this large intron should be spliced out for the normal function of the gene. This intron in the Ler ecotype is only $456 \mathrm{bp}$, which has a left border and a right border similar to that of Col ecotype. Moreover, this intron in Arabidopsis lyrata and many other plant species is also hundreds of bp (Table 2). These data suggest that recently after the divergence of $\mathrm{Col}$ and Ler ecotypes, a transposon was inserted in this intron. A semi-quantitative RT-PCR analysis indicated that the presence of this large intron has no large effect on the mRNA level of this gene (Figure 3C). 
Table 2. Lengths of intron AT3G05410.2-2 and its counterparts in other plants.

\begin{tabular}{cc}
\hline Organism & Length (bp) \\
\hline Arabidopsis thaliana (Col-0) & 5748 \\
Arabidopsis thaliana (Ler) & 456 \\
Arabidopsis lyrata & 461 \\
Capsella rubella & 391 \\
Citrus sinensis & 77 \\
Populus euphratica & 83 \\
Vitis vinifera & 18 \\
Oryza sativa & 254 \\
Populus trichocarpa & 130 \\
Sesamum indicum & 2903 \\
\hline
\end{tabular}

AT5G13250.1 encodes a RING finger protein. The third intron of this gene, AT5G13250.1-3, was annotated to be $5670 \mathrm{bp}$. Like AT3G05410.2, the protein sequence encoded by the exon after this intron is well-conserved in different plants (Figure S3). RT-PCR was carried out to validate this intron. Sequencing result indicated that this intron is $3 \mathrm{bp}$ into the predicted following exon. This intron was also annotated to have several short transposable elements. Unlike the large introns analyzed above, the overall sequence of this intron is not a transposon or repetitive sequence, which are only $530 \mathrm{bp}$ and constitute $9.3 \%$ of the intron. Analysis of the homologs of this gene in various plant species, including rice, suggests that they all have a large intron of several $\mathrm{kb}$ or even more than $10 \mathrm{~kb}$ at the corresponding location (Table 3). During evolution, this intron remained very large.

Table 3. Lengths of intron AT5G13250.1-3 and its counterparts in other plants.

\begin{tabular}{cc}
\hline Organism & Length (bp) \\
\hline Arabidopsis thaliana (Col-0) & 5670 \\
Arabidopsis lyrata & 8873 \\
Populus euphratica & 6986 \\
Citrus sinensis & 5302 \\
Vitis vinifera & 6587 \\
Oryza sativa (Chromosome 4) & 9945 \\
Oryza sativa (Chromosome 12) & 16,721 \\
Populus trichocarpa (linkage group 1) & 6684 \\
Populus trichocarpa (linkage group 3) & 6244 \\
Sesamum indicum & 5931 \\
\hline
\end{tabular}

AT2G34100 encodes a protein with homologs only found in some species of the Brassica family. AT2G34100.1 and AT2G34100.2 encode the same protein sequence. AT2G34100.2 has a longer 5'-UTR, whose coding sequence is far upstream. The second intron of AT2G34100.2 is 11,602 bp, and was validated by our RT-PCR analysis (Figure 2E). According to the annotation, in this intron, there are 13 genes or TEs. Ten of them are in the reverse direction of AT2G34100. The longest one among those, AT2TE63800, is $4541 \mathrm{bp}$.

AT5G22090 encodes a protein with a Fantastic Four (FAF) domain. FAF belongs toa family of proteins that regulate the size of the plant shoot meristem by modulating the CLV3-WUS feedback loop. Similar to At2G34100, AT5G22090 was annotated to have two splice variants that encode the same protein sequences. AT5G22090.2 has a large intron of $5081 \mathrm{bp}$ (Figure 2F). In this intron, there are three transposable elements, which are all in the reverse direction of the gene.

\section{Discussion}

In this study, we show clear evidence that some introns in Arabidopsis could be much larger than usual. Introns in Arabidopsis are mostly 50 to $300 \mathrm{bp}$, which account for $87.04 \%$ of the total introns. 
Introns larger than $1 \mathrm{~kb}$ account only for $0.77 \%$ of all the introns, and there are only 16 annotated introns larger than $5 \mathrm{~kb}$ in the whole genome. We chose eight of them for validation, and found that six of them are true introns. We also discovered an additional large intron that is $6070 \mathrm{bp}$ length. These data suggest that the actual genetic structures in Arabidopsis could be more complicated than what is thought, and some genes with extremely large introns could be misannotated or overlooked. A misannotation of the large intron between the 5' UTR sequences could give the wrong position of the promoter of the gene, while a misannotation of the large intron between the coding sequences could cause the annotation to miss a part of the gene.

Six out of the seven ELIs reported in this study are mainly transposons, multiple transposons (i.e., transposons in transposons), or full of TEs. It is well known that the genome of Arabidopsis is very compact, and only a very small part of its genome is composed of transposons. The genome of many other species, including other plants, have a much higher presence of transposons [3,5,8]. Transposon insertions and DNA sequence translocations into introns could increase the complexity of the genome and the difficulty of genome annotation, especially for higher eukaryotic species other than Arabidopsis.

Introns in the genome of Arabidopsis and other plants are usually small (shorter than a few hundred base pairs) [4-6,9]. In extreme cases, an intron could be only 1 bp [10]. Our results suggest that transposon insertions or DNA translocations could increase the size of introns to several kb or even larger. These sequences could provide the materials for genome evolution, increase the complexity of gene structures, and finally be functional, as large introns could be important for the regulation of gene expression and function [11-13]. In the case of AT5G13250.1-3, all the introns at this position in flowering plants are very large, suggesting they may have functional elements. On the other hand, small introns seem to be common in most of the genes. During evolution, larger introns might have become smaller through DNA deletion during DNA replication if they do not have functional elements, since introns with a smaller size were more favored by the genome.

Our results show that the insertion of transposons in the introns of some genes might have little or no effect on the splicing of the pre-mRNA. Mutants caused by transfer-DNA (T-DNA) and transposon insertions are widely used in the study of Arabidopsis and other plant species [14-17]. These insertions are usually only several $\mathrm{kb}$, which are comparable to or even smaller than the introns reported in this study. Often, we can see T-DNA and transposons inserted in introns of genes in the insertional mutants of Arabidopsis (http://signal.salk.edu/cgi-bin/tdnaexpress/). These mutants were once seen as null alleles, although it is conceivable that some of the insertions in the introns could abolish the splicing, our study also suggests that some of the introns with insertions of several kb length could be spliced out with little or no problem.

Supplementary Materials: Supplementary files can be found at www.mdpi.com/2073-4425/8/8/200/s1. Figure S1: Gene structure and RT-PCR analysis of AT3G52700.1, Figure S2: Protein sequence alignment of AT3G05410.2 and its homologs in other species, Figure S3: Protein sequence alignment of AT5G13250.1 and its homologs in other species, Table S1: Sequences of the primers used in this study, Table S2: Annotated introns larger than $5 \mathrm{~kb}$ in genes that are not protein coding in Arabidopsis thaliana.

Acknowledgments: This work was supported by grants from the Natural Science Foundation of China (31570182) and the Beijing Natural Science Foundation (5172022).

Author Contributions: Hongbo Gao and Ning Chang designed the study and analyzed the data; Ning Chang, Qingqing Sun, and Jinglei Hu carried out the experiments; Ning Chang, Chuangjing An, and Hongbo Gao prepared the manuscript.

Conflicts of Interest: The authors declare no conflict of interest. The founding sponsors had no role in the design of the study; in the collection, analyses, or interpretation of data; in the writing of the manuscript, and in the decision to publish the results.

\section{References}

1. Roy, S.W.; Gilbert, W. The evolution of spliceosomal introns: Patterns, puzzles and progress. Nat. Rev. Genet. 2006, 7, 211-221. [PubMed]

2. Mourier, T.; Jeffares, D.C. Eukaryotic intron loss. Science 2003, 300, 1393. [CrossRef] [PubMed] 
3. Lander, E.S.; Linton, L.M.; Birren, B.; Nusbaum, C.; Zody, M.C.; Baldwin, J.; Devon, K.; Dewar, K.; Doyle, M.; FitzHugh, W.; et al. Initial sequencing and analysis of the human genome. Nature 2001, 409, 860-921. [CrossRef] [PubMed]

4. Arabidopsis Genome Initiative. Analysis of the genome sequence of the flowering plant Arabidopsis thaliana. Nature 2000, 408, 796-815.

5. Schnable, P.S.; Ware, D.; Fulton, R.S.; Stein, J.C.; Wei, F.; Pasternak, S.; Liang, C.; Zhang, J.; Fulton, L.; Graves, T.A.; et al. The B73 maize genome: complexity, diversity, and dynamics. Science 2009, 326, 1112-1115. [CrossRef] [PubMed]

6. Rensing, S.A.; Lang, D.; Zimmer, A.D.; Terry, A.; Salamov, A.; Shapiro, H.; Nishiyama, T.; Perroud, P.F.; Lindquist, E.A.; Kamisugi, Y.; et al. The Physcomitrella genome reveals evolutionary insights into the conquest of land by plants. Science 2008, 319, 64-69. [CrossRef] [PubMed]

7. Deutsch, M.; Long, M. Intron-exon structures of eukaryotic model organisms. Nucleic Acids Res. 1999, 27, 3219-3228. [PubMed]

8. Nystedt, B.; Street, N.R.; Wetterbom, A.; Zuccolo, A.; Lin, Y.C.; Scofield, D.G.; Vezzi, F.; Delhomme, N.; Giacomello, S.; Alexeyenko, A.; et al. The Norway spruce genome sequence and conifer genome evolution. Nature 2013, 497, 579-584. [CrossRef] [PubMed]

9. Zhang, R.; Calixto, C.P.G.; Marquez, Y.; Venhuizen, P.; Tzioutziou, N.A.; Guo, W.; Spensley, M.; Entizne, J.C.; Lewandowska, D.; Ten Have, S.; et al. A high quality Arabidopsis transcriptome for accurate transcript-level analysis of alternative splicing. Nucleic Acids Res. 2017, 45, 5061-5073. [CrossRef] [PubMed]

10. Guo, L.; Liu, C.M. A single-nucleotide exon found in Arabidopsis. Sci. Rep. 2015, 5, 18087. [CrossRef] [PubMed]

11. Bradley, D.; Carpenter, R.; Sommer, H.; Hartley, N.; Coen, E. Complementary floral homeotic phenotypes result from opposite orientations of a transposon at the plena locus of Antirrhinum. Cell 1993, 72, 85-95. [CrossRef]

12. Kim, M.J.; Kim, H.; Shin, J.S.; Chung, C.H.; Ohlrogge, J.B.; Suh, M.C. Seed-specific expression of sesame microsomal oleic acid desaturase is controlled by combinatorial properties between negative cis-regulatory elements in the SeFAD2 promoter and enhancers in the 5'-UTR intron. Mol. Genet. Genomics 2006, 276, 351-368. [CrossRef] [PubMed]

13. Rigal, M.; Kevei, Z.; Pélissier, T.; Mathieu, O. DNA methylation in an intron of the IBM1 histone demethylase gene stabilizes chromatin modification patterns. EMBO J. 2012, 31, 2981-2993. [CrossRef] [PubMed]

14. Alonso, J.M.; Stepanova, A.N.; Leisse, T.J.; Kim, C.J.; Chen, H.; Shinn, P.; Stevenson, D.K.; Zimmerman, J.; Barajas, P.; Cheuk, R.; et al. Genome-wide insertional mutagenesis of Arabidopsis thaliana. Science 2003, 301, 653-657. [CrossRef] [PubMed]

15. Sallaud, C.; Gay, C.; Larmande, P.; Bès, M.; Piffanelli, P.; Piégu, B.; Droc, G.; Regad, F.; Bourgeois, E.; Meynard, D.; et al. High throughput T-DNA insertion mutagenesis in rice: A first step towards in silico reverse genetics. Plant J. 2004, 39, 450-464. [CrossRef] [PubMed]

16. Tissier, A.F.; Marillonnet, S.; Klimyuk, V.; Patel, K.; Torres, M.A.; Murphy, G.; Jones, J.D. Multiple independent defective suppressor-mutator transposon insertions in Arabidopsis: A tool for functional genomics. Plant Cell 1999, 11, 1841-1852. [CrossRef] [PubMed]

17. Chang, Y.; Long, T.; Wu, C. Effort and contribution of T-DNA Insertion mutant library for rice functional genomics research in China: Review and perspective. J. Integr. Plant Biol. 2012, 54, 953-966. [CrossRef] [PubMed]

(C) 2017 by the authors. Licensee MDPI, Basel, Switzerland. This article is an open access article distributed under the terms and conditions of the Creative Commons Attribution (CC BY) license (http://creativecommons.org/licenses/by/4.0/). 